Ireneusz Ziemiński

Uniwersytet Szczeciński

ireziem@univ.szczecin.pl

\title{
Nie-ludzka nieśmiertelność - \\ kilka filozoficznych uwag na temat idei wieczności w poezji Zbigniewa Herberta
}

\author{
Inhuman Immortality: Some Philosophical Remarks on the Idea of Eternity \\ in the Poetry of Zbigniew Herbert
}

\begin{abstract}
Abstact: The article is an attempt at philosophical reconstruction of the idea of eternal life present in the poetry of Zbigniew Herbert. The author focuses on demonstrating difficulties concerning both the heavenly (transcendental) eternity, which is a new form of human existence after death, and the mundane (immanent) eternity, which takes shape of the immortal fame (the memory of the generations) or the moments of eternity experienced sometimes by people (i.e. the lack of awareness of the passage of time). An example of the heavenly eternity is the immortality of the soul or the resurrection of the body; both of these possibilities mean, according to Herbert, a new (perfect and infinite) form of existence, completely alien to human nature (which is imperfect and finite). For this reason man doesn't desire such eternity, as it would be a transformation of his nature into some other, non-human (divine or angelic) being. A model example of the mundane eternity are the in-depth experiences (e.g. an aesthetic contemplation of beauty), when the individual loses the awareness of the destructive passage of time, or even of the imminent death, and succumbs to the momentary illusion that their existence is eternal. Herbert, however, seems to accept a third possibility which is a way of sceptics, who don't believe neither in the transcendental eternity nor in the mundane one and live in a continuous suspension between both these ways.
\end{abstract}

Keywords: Zbigniew Herbert, philosophy, poetry, death, immortality, eternal life

Streszczenie: Artykuł jest próbą filozoficznej rekonstrukcji idei życia wiecznego, obecnej w poezji Zbigniewa Herberta. Autor skupia się na pokazaniu trudności związanych zarówno z wiecznością niebiańską (transcendentna), polegającą na nowej formie ludzkiego istnienia po śmierci, jak i z wiecznością ziemską (immanentną), polegającą na nieśmiertelnej sławie (pamięć pokoleń) lub dostępnych niekiedy ludziom chwilach wieczności (oznaczających brak świadomości upływu czasu). Przykładem wieczności niebiańskiej jest nieśmiertelność duszy lub zmartwychwstanie ciał; obie możliwości oznaczają, zdaniem Herberta, radykalnie nową (doskonałą i nieskończoną) formę istnienia, zupełnie obcą ludzkiej 
(niedoskonałej i skończonej) naturze. Z tego powodu człowiek takiej wieczności nie pragnie, byłaby ona bowiem transformacją jego natury w inny, nie-ludzki (boski, anielski) byt. Wzorcowym przykładem wieczności ziemskiej są głębokie przeżycia (chociażby estetyczna kontemplacja piękna), kiedy to podmiot traci świadomość niszczącego upływu czasu, a nawet grożącej mu śmierci, ulegając chwilowemu złudzeniu, że trwa wiecznie. Herbert zdaje się jednak opowiadać za możliwością trzecią, która jest drogą sceptyków, niewierzących ani w wieczność transcendentną, ani immanentną, żyjących w ciągłym zawieszeniu między obiema drogami.

Słowa kluczowe: Zbigniew Herbert, filozofia, poezja, śmierć, nieśmiertelność, życie wieczne

\section{Poezja a filozofia}

Interpretacja poezji Herberta jest dla filozofa zadaniem karkołomnym, ponieważ za pomocą spekulatywnych narzędzi pojęciowych trudno uchwycić jej artystyczną finezję. Dodatkową przeszkodą są (z pozoru oczywiste) skojarzenia filozoficzne (jak figura Cogito), które mogą prowadzić do mylnych interpretacji. Przykładem jest wiersz Pan Cogito opowiada o kuszeniu Spinozy ${ }^{1}$; wprawdzie zawiera on trafną charakterystykę Erazma, Kartezjusza i Spinozy, to jednak jego sens nie redukuje się do tych historycznych odniesieńn ${ }^{2}$.

Dodatkową trudnością w filozoficznej rekonstrukcji poezji Herberta jest wszechobecna w jego utworach ironia ${ }^{3}$, którą potrafił kąsać równie dotkliwie jak Sokrates. Pod piórem poety staje się ona niekiedy - pełnym moralnego wstrętu - szyderstwem. Ilustracją jest wiersz Co myśli Pan Cogito o piekle, ukazujący artystów w państwie Belzebuba, tworzących sztukę w zamian za wygodne życie. Ironia Herberta bywa też wyrazem politowania dla ograniczoności ludzkiego umysłu czy prymitywnych form osądzania Boga (Rozmyślania Pana Cogito o odkupieniu). Ironia ta jednak - w przeciwieństwie do sokratejskiej - nie jest maską, Herbert bowiem szczerze przyznaje się do niewiedzy. Mając świadomość, że każdy (także filozof i poeta) tkwi w jaskini swych fikcyjnych wyobrażeń, Herbert bywa wyrozumiały

1 Wszystkie wiersze Herberta cytuję według wydania: Z. Herbert, Wiersze zebrane, oprac. R. Krynicki, Kraków 2008.

2 W rzeczywistości Erazm także skutecznie dbał o dochody, a Kartezjuszowi nie udało się podjąć królewskiego stypendium; wykazał się za to przebiegłością w procesach, którymi nękano go w Niderlandach. Mimo tych drobiazgów zarysowane przez poetę portrety są wiarygodne. Niezależnie też od tego, czy Herbert zaczerpnął opisaną historyjkę z tekstu Kazimierza Brandysa Rynek. Wspomnienia z teraźniejszości, czy też obaj znali ją z innego źródła, Herbert oddał portret Spinozy trafniej niż Brandys. Zob. R. Nycz, "Niepewna jasność” tekstu i „wierność interpretacji”. Wokót wiersza Zbigniewa Herberta „Pan Cogito opowiada o kuszeniu Spinozy”, „Teksty Drugie" 2000, nr 3, s. 136-138.

${ }^{3}$ Ironia, doprowadzona przez Herberta do perfekcji, uchodzi za znak rozpoznawczy jego poezji. Zob. S. Barańczak, Uciekinier z Utopii. O poezji Zbigniewa Herberta, Londyn 1984, s. 73. 
dla ludzkich ułomności, od których nie uwolnił się ani dbający o dochody Kartezjusz, ani przebiegły Erazm z Rotterdamu, ani nawet Spinoza, pragnący rozumem poznać Boga; może dlatego ironia poety bywa też formą współczucia (Kant. Ostatnie dni) ${ }^{4}$.

W analizie poezji Herberta nie można też zapomnieć o jego krytyce myślicieli spekulatywnych, wierzących, że za pomocą definicji uchwycili tajemnicę bytu. Ci dialektyczni szalbierze, których pojęcia są jak cepy ${ }^{5}$, a składnia „pozbawiona urody koniunktiwu” (Potega smaku, s. 523), budują absurdalne wizje życia społecznego, w stylu komunizmu czy pozytywistycznej religii ludzkości, co sugeruje, „że wszelka filozofia/ jest zbyteczna/ a nawet szkodliwa" (Ala ma kota. Wobronie analfabetyzmu); z tego powodu poeta przestrzega filozofów, aby nie wcielali swych idei w życie ${ }^{6}$. Zdolność redukowania bogactwa rzeczy do kilku prostych formuł sprawia jednak, że filozofowie wierzą, iż poznali tajemnicę świata. Żartobliwym opisem tej „nadprodukcji idei” jest portret myśliciela, który odkrył nieskończoność tak olbrzymią, że „za trzy a może cztery/ kwadranse wieczności/ przerośnie nawet/ jego głowę"; ukoronowaniem wysiłku jest „twarde i bezbarwne” słowo byt, redukujące świat do pozoru (Uprawa filozofii, s. 46) ${ }^{7}$. Nawet jednak odkrywszy tajemnicę, filozof nie może się ucieszyć ani zapłakać, byt bowiem nigdy się nie wzrusza. Demaskacja takich bezowocnych dążeń znajduje dopełnienie

${ }^{4}$ Wiersz ten stanowi krytykę zarówno oświeceniowej idei dobroci natury, jak i idei Opatrzności. Ironiczne jest to, że los starego filozofa, który stał się widmem, przeczy jego własnej teorii - nie tylko idei racjonalności człowieka i przyrody, ale także niemożliwości metafizyki. Utwór można też odczytać w duchu negatywnych obrazów Immanuela Kanta, które - pod wpływem Heinricha Heinego - stały się legendarne; należy jednak pamiętać, że nie wszystkie tezy Heinego o Kancie są prawdziwe. Zob. O. Höffe, Immanuel Kant, tłum. A.M. Kaniowski, Warszawa 2003 , s. 40.

${ }^{5}$ Określenie to nie dotyczy tylko marksistów, lecz także dogmatycznych racjonalistów, wierzących, że odkryli absolut. W innym wierszu (Do Henryka Elzenberga w stulecie jego urodzin) Herbert używa kategorii myślenia młotem; wprawdzie jej negatywny sens jest oczywisty, jednak warto pamiętać, że do podobnej metafory odwoływał się Friedrich Nietzsche, rozumiejąc ją pozytywnie. Autentyczne myślenie jest podobne do młota Jahwe, kruszącego skały (Jr 23, 28), rozbija bowiem utarte schematy pojęciowe; myślenie młotem przypomina także rzeźbiarza, wykuwającego właściwy kształt posągu.

${ }^{6}$ Podobnie oceniał niektórych poetów i teologów: „strach pomyślećl co może uczynić sztuka czytania/spuszczona z łańcucha/ szkoła pisania/ nie zadowalając się konstatacją/ że wszystko z wody/albo wszystko z ognia/ a nie drukiem/ dłubaniem zaostrzonym dziobem pióra/ w tekstach// i tak powstają/ pożal się Boże/ wciąż nowe/ traktaty/ bulle/ rewokacje/ stosy" (Co mogę jeszcze zrobić dla Pana, s. 686-687).

7 Równie ironiczny jest wiersz bez tytułu, rozpoczynający się od słów „Pryśnie klepsydra”: „szpalerem mądrych dialogów/suchym krokiem mierniczych/chodzą filozofowie/absolut mylą i liczą”. Niechęć Herberta do słowa „byt” wynika stąd, że poeta dostrzega raczej wielość osobnych rzeczy, niż ich wspólne, abstrakcyjne cechy. „Byt rozsypał się mu w zbiór przedmiotów i te go tylko interesują”. K. Dybciak, Gry i katastrofy, Warszawa 1980, s. 153. 
w rozmowie z Markiem Aureliuszem, którego filozoficzna łacina ${ }^{8}$ nie zna okrzyku trwogi i nie koi łez (Do Marka Aurelego) ${ }^{9}$.

Mierząc się z wierszami Herberta trzeba też pamiętać, że - pomimo filozoficznych studiów, odbytych przez niego pod kierunkiem Henryka Elzenberga - ostatecznie nie został filozofem, lecz poetą. Powodem mogło być to, że - w przeciwieństwie do abstrakcyjnych schematów i pojęć - poezja ukazuje konkretność istnienia, naśladując głosy ptaków i sen kamieni (Przypowieść). Wprawdzie nawet język poezji nie jest doskonały (Chciatbym opisac), to jednak odsłania różnorodność świata. Skoro zaś filozof takim plastycznym językiem nie dysponuje, to powstaje groźba, że - pisząc o Herbercie - dokona cudu odwrotnego do tego z Kany Galilejskiej, zamieniając wino poezji w wodę słów ${ }^{10}$. Niebezpieczeństwo to nie jest wydumane, Herbert miał bowiem wyjątkową umiejętność przekształcania złożonych pojęć i rozbudowanych argumentacji filozoficznych w sugestywne obrazy poetyckie ${ }^{11}$. W kontekście idei życia wiecznego przykładem jest wiersz $U$ wrót doliny, którego treść w filozoficznej parafrazie łatwiej zaciemnić lub zbanalizować niż pogłębić. Niezależnie jednak od tych trudności,

${ }^{8}$ Na pierwszy rzut oka mogłoby się wydawać, że Herbert popełnił błąd, Rozmyślania Marka Aureliusza zostały bowiem napisane po grecku; według świadectwa Adama Zagajewskiego zresztą sam poeta, odkrywszy pomyłkę, żartował z siebie. Zob. A. Zagajewski, Niejasne przestanie [w:] Poeci czytają Herberta, zebr., oprac. A. Franaszek, Kraków 2009, s. 169-170. Sprawa jest jednak bardziej skomplikowana, ponieważ w kolejnych edycjach tekstu Herbert żadnej korekty nie wprowadził. Powodem nie była zapewne jedynie chęć zachowania słowa „łacina” jako rymu do „zaczyna” czy trudności z zastąpieniem wyrażenia „twa łacina” słowami „twoja greka”. Bardziej prawdopodobne wydaje się, że odwołanie do filozoficznej łaciny, która nie zna lęku, miało być w zamierzeniu poety opisem rzymskiego modelu kultury, która nie pozwala na poddanie się lękowi. Potwierdzeniem tej sugestii może być to, że stoicyzm rzymski był bardziej radykalny od stoicyzmu greckiego (przynajmniej w kwestii nakazu zachowania obojętności wobec cierpienia i śmierci). Jednym z powodów było silne nachylenie epistemologiczne stoicyzmu greckiego, tymczasem w stoicyzmie rzymskim na czoło wysuwały się kwestie praktyczno-życiowe. Poza tym Marek Aureliusz w wierszu Herberta urasta do rangi swoistego symbolu łacińskiej kultury Rzymu, z jej elitarnym etosem żołnierza i władcy, uosabianym przez człowieka mężnego, znoszącego bez skargi wszelkie przeciwności losu. „Filozoficzna łacina” nie musi zatem oznaczać języka, w którym spisane zostały Rozmyślania rzymskiego cesarza i filozofa, lecz specyficzny model myślenia, w którym nie ma miejscu na lęk ani tym bardziej - „bezradny płacz”.

${ }_{9}$ Wiersz ten dobrze oddaje nastrój Rozmyślań, które nie są streszczeniem doktryny filozoficznej, lecz wyrazem zmagań z życiem, opornym wobec rygorów stoickiego ideału. Julian Kornhauser widzi w tym utworze zarówno opis traumy wojennej Herberta, jak i sformułowanie programu poetyckiego. Zob. J. Kornhauser, „Struna światta” - między ocaleniem a niepokojem, „Teksty Drugie” 2000, nr 3, s. 22.

${ }_{10}$ Porównanie to zaczerpnąłem z krótkiego tekstu Romana Brandstaettera Cud księdza Michata, którego bohater co tydzień publikuje swoje medytacje religijne, zamieniając wino Ewangelii w wodę komentarzy. Zob. R. Brandstaetter, Bardzo krótkie i nieco dtuższe opowieści, Poznań 1984, s.108.

${ }_{11}$ Z kolei w wierszu Dlaczego klasycy, znakomicie streścił Wojnę peloponeska Tukidydesa. Zob. A. Sosnowski, „Epizod” [w:] Poeci czytaja Herberta, dz. cyt., s. 73-74. 
Herbert widział między filozofią a poezją istotne powiązania ${ }^{12}$. W liście do Elzenberga zwierzał się, że obca jest mu abstrakcyjna filozofia akademicka, bliska zaś filozofia egzystencji, polegająca na przeżywaniu pytań egzystencjalnych, dotyczących sensu życia, cierpienia czy śmierci ${ }^{13}$. Do tego drugiego rozumienia filozofii nawiązuję w tym artykule, podejmując problem sensowności, spójności i atrakcyjności życia wiecznego (nieśmiertelności) ${ }^{14}$, tak jak został on zobrazowany w poezji Herberta. Najpierw naświetlę kontekst problemu, następnie opiszę dwa modele życia wiecznego (wieczność niebiańską i wieczność ziemską), na koniec zaś podejmę kwestię sceptycyzmu poety. $Z$ góry chciałbym przy tym zaznaczyć, że będę rozważał poezję Herberta nie diachronicznie, lecz synchronicznie, próbując zrekonstruować filozoficzną ideę wieczności zawartą w jego wierszach. Głównym celem artykułu jest bowiem nakreślenie spójnego rozwiązania problemu wieczności, jaki daje się zauważyć w poezji Herberta, nie zaś historycznie i filologicznie wierna rekonstrukcja przemian jego poetyckiego warsztatu czy światopoglądu; z tego powodu pominę ewolucję ideową poety, zestawiając ze sobą utwory, pochodzące z różnych okresów jego życia i twórczości. Przykładem mogą być takie wiersze, jak - z jednej strony - zbliżony do filozoficznej (stoickiej) medytacji tekst Pan Cogito obserwuje zmartego przyjaciela czy zbudowany na zasadnie parodii traktatu teologicznego Raj teologów, bądź też - z drugiej strony - pełen żalu i gniewu tekst Polegtym poetom czy wskazujący na osobiste zmagania z losem tekst Brewiarza, rozpoczynający się od słów „Panie, wiem, że dni moje są policzone...” (s. 640), w którym można wręcz usłyszeć łamiący się głos umierającego.

\section{Śmierć a życie wieczne}

Kwestia życia wiecznego pojawia się często w kontekście doświadczenia zła i niesprawiedliwości. Skoro bowiem w doczesności ludzie dobrzy cierpią niezasłużone męki, okrutnicy zaś opływają w dostatki, to należy postulować życie po śmierci, w którym krzywdy zostaną wynagrodzone, a zbrodnie ukarane. $\mathrm{Na}$ gruncie teizmu problem ten ma dodatkowy wymiar, związany z próbami usprawiedliwienia Boga za zło w świecie. Jeśli bowiem każdy człowiek dostąpi pełni życia po śmierci jako nagrody za cierpienia doczesne, to można przypuszczać, że dzisiejsze zło zostanie odkupione. W poezji Herberta problem ten nie

12 Jednym z nich był estetyczny aspekt języka filozofii, o czym Herbert - według relacji Konstantego A. Jeleńskiego - planował artykuł, chociaż go nigdy nie napisał. Zob. P. Siemaszko, Piękno jako odpowiedż. O malarskich fascynacjach Zbigniewa Herberta, „Ethos” 2000, nr 4, s. 183 , przyp. 9.

${ }_{13}$ Zob. M.K. Siwiec, Zbigniew Herbert-twórca i źródto. Droga do źródta i źródto w wierszu „Ścieżka”, „Filo-Sofija” 2013, nr 3, s. 107. W liście do Jerzego Zawieyskiego Herbert użył kategorii „myślenie dramatyczne”, za myśliciela dramatycznego uznając Sørena Kierkegaarda. Zob. J. Kopciński, Nastuchiwanie. Sztuki na gtosy Zbigniewa Herberta, Warszawa 2008, s. 12.

${ }^{14}$ Terminów tych używam zamiennie na oznaczenie życia, z którego usunięta została śmierć. 
występuje; chociaż poeta był wyczulony na okrucieństwa dziejów, to jednak nie traktował nieśmiertelności jako narzędzia odkupienia zła. Bliższe było mu naturalistyczne rozumienie człowieka jako istoty organicznej, świadomej i podatnej na cierpienie; znaczy to, że ból jest naturalnym elementem życia i nie należy go demonizować (Pan Cogito rozmyśla o cierpieniu). W przeciwieństwie do Czesława Miłosza czy Witolda Gombrowicza, którzy nie godzili się z okrucieństwem przyrody ( $\mathrm{w}$ walce o przetrwanie upatrując nieomal działań szata$\mathrm{na}^{15}$ ), Herbert kwestię tę stawiał nieco mniej dramatycznie. Jeśli bowiem nawet istnieje diabeł, to ma cechy ludzkie - zwłaszcza obojętność na dobro i zło (Diabet); wprawdzie bywa leniwy i powolny, to jednak jest też uparty, wobec czego „przeżyje wszystkich” (Diabet rodzimy, s. 341). Nie znaczy to, że zło banalne i swojskie przestaje być złem ${ }^{16}$; Herbert nie widzi jednak potrzeby rozprawiania się z nim za pomocą spekulacji teodycealnych - tyleż pomysłowych, co nieskutecznych ${ }^{17}$. Jeszcze surowiej oceniał utopie, które gloryfikują okrucieństwa dokonywane w imię fikcyjnego dobra w przyszłości ${ }^{18}$.

Problem życia wiecznego jest także podejmowany w perspektywie natury człowieka, który nie godzi się ze swoją śmiertelnością, ponieważ w życiu doczesnym nie potrafi zrealizować swych pragnień - poznania pełnej prawdy czy osiągnięcia szczęścia. Chociaż ta antropologiczna perspektywa jest Herbertowi bliska, to jednak rozważa on nie tyle ludzkie pragnienie nieśmiertelności, ile atrakcyjność konkretnych wyobrażeń wieczności jako lekarstwa na śmierć.

Częstym obrazem związanym ze śmiercią w poezji Herberta są - z jednej strony - okrucieństwa władców, prowadzących ludzi na rzeź, z drugiej - ofiary niewinnych, którzy usiłowali się im sprzeciwić. Poeta zdaje się wręcz sugerować, że główną treścią dziejów jest zabijanie w imię obłąkańczych idei, w które

$15 \mathrm{O}$ zagadnieniu zła, także zła naturalnego, wnikliwie i wyczerpująco pisze Łukasz Tischner w dwu znakomitych książkach: Sekrety manichejskich trucizn. Mitosz wobec zta (Kraków 2001) oraz Gombrowicza milczenie o Bogu (Kraków 2013). Według Miłosza zło obecne w przyrodzie jest możliwym argumentem przeciw teizmowi; zdaniem Gombrowicza może być nawet argumentem na rzecz istnienia szatana.

16 Według Barańczaka Herbert banalizuje zło, o czym świadczy jego przekonanie o niemożliwości przeniesienia greckich mitów do współczesności, w której tracą one swój tragiczny wymiar. Zob. S. Barańczak, dz. cyt., s. 117. Jednocześnie jednak należy odnotować, że sprawa się komplikuje, jeśli uwzględnimy wiersz Dęby z Elegii na odejście, w którym wyraźnie obecna jest zarówno bezradność rozumu wobec zła, jak i gniew oraz bunt przeciwko Bogu (niezależnie od tego, czy mamy w Nim widzieć stwórcę przyrody czy Autora dziejów).

17 Zdaniem Ryszarda Przybylskiego, Herbert odrzuca wszystkie teodycee, także chrześcijańską, są bowiem równie groźne, jak utopie społeczne. Zob. S. Barańczak, dz. cyt., s. 14-15. Również przywołany w poprzednim przypisie wiersz Dęby zdaje się wykluczać możliwość teodycei; z jednej bowiem strony nie można wykluczyć, że autorem świata jest „demiurg nikczemnych tablic statystycznych/ który gra w kości zawsze wychodzi na swoje”, z drugiej - nasze bezradne pytania giną w otchłani tajemnicy, niezdolne pokonać tkwiącej u ich podstaw rozpaczy.

${ }^{18}$ Każda utopia zaczyna się od wymyślania idealnego świata a kończy obozem koncentracyjnym. Zob. tamże, s. 127. 
nie wierzą nawet głoszący je tyrani $(D e s z c z)^{19}$. Każdy bowiem, kto stawi opór, zostanie wdeptany w grunt, a jedynym świadkiem kaźni będzie milczący dozorca (Odpowiedź); wojny zresztą, jak sarkastycznie pisze Herbert, zawsze toczą się o sprawy najważniejsze, to znaczy o kolor munduru (Żotnierz $)^{20}$. Najbardziej smutne jest jednak to, że ludzie - ogarnięci atawistyczną pasją krwi pędzą w rytmie bębnów na rzeź, jakby wierzyli, że „śmierć niestraszna, kiedy tłumna" (Pieśn o bębnie, s. 151).

Szczególnie trudno pogodzić się z heroiczną śmiercią ludzi, którzy w nagrodę otrzymali zapomnienie lub wzgardę (Pożegnanie września, Polegtym poetom). Ich ofiara brała się jednak nie tylko z chęci obrony takich wartości, jak wolność, honor czy wierność, lecz także z potrzeby bohaterstwa; ostatecznie bowiem nawet śmierć może być widokiem wspaniałym, jeśli spojrzeć z właściwej perspektywy (Ofiarowanie Ifigenii) ${ }^{21}$. Sugeruje to, że - w końcowym rozrachunku - znikają różnice między oprawcami i ofiarami, ponieważ „złych i dobrych/ porówna płytki dół" (Chrzest, s. 79).

Historyczna perspektywa patrzenia na śmierć powoduje, że nawet lęk przed nią bardzo często miewa charakter konkretny; wprawdzie może przybierać postać metafizycznej trwogi przed nicością (Dęby, Potwór Pana Cogito), przejawia się jednak też w postaci strachu przed informacją, że lokal został spalony i należy ostrzec kolegę (Nasz strach). Człowieka można przecież zastraszyć, a nawet wykrwawić, zwłaszcza że z perspektywy kosmosu pięć litrów krwi to rzecz bez znaczenia (Pan Cogito myśli o krwi). Ten aspekt śmierci jest na tyle istotny, że także w opisach biologicznego procesu umierania Herbert stosował porównania batalistyczne; agonia wszak to walka toczona wewnątrz organizmu przez wrogie siły, stosujące różne strategie przechytrzenia wroga (Pal). W przeciwieństwie jednak do śmierci zadanej przez ludzi, śmierć biologiczna jest wpisana w naturalny porządek rzeczy, którego zmienić nie sposób (Pan Cogito na zadany

19 W bohaterze tego wiersza można upatrywać portretu człowieka, który postradał zmysły, utożsamiając się z Rolandem czy Hannibalem. Można tu jednak również widzieć uniwersalny portret żołnierza, ginącego zarówno pod Grunwaldem, jak i pod Verdun; stąd poległy Feliksiak jest równie ważny, jak historyczni czy mityczni herosi.

${ }^{20}$ Opinia ta pojawia się często w Próbach Michela de Montaigne’a, który źródła wojen upatrywał w tym, że ludzie są inaczej ubrani, mówią innym dialektem lub mieszkają po drugiej stronie rzeki. W poezji Herberta nie ma jednak odniesień do francuskiego filozofa, przynajmniej formułowanych explicite. Warte dalszego zbadania byłyby jednak ewentualne związi sceptycyzmu Herberta ze sceptycyzmem Montaigne’a.

${ }^{21}$ Fraza o wspaniałym widoku śmierci, puentująca fragment prozy poetyckiej Ofiarowanie Ifigenii („Widok jest pyszny, jeśli przywołać na pomoc odpowiednią perspektywę”, s. 219) ma też wymiar ironiczny, Herbert krytykuje tu bowiem nadużycie, jakim są ofiary z ludzi składane bogom. Podobnie można interpretować śmierć bohaterską w obronie wiary, narodu czy ojczyzny; mimo iż uchodzi ona za heroiczną i jest stawiana za wzór przyszłym pokoleniom, to jednak może się okazać równie niepotrzebna, okrutna i bezsensowna, jak śmierć Ifigenii. Wykładnię taką zdają się potwierdzać wiersze oskarżające tych, którzy z heroicznej ofiary bohaterów ośmielają się korzystać lub do niej cynicznie nawoływać (Pożegnanie września, Guziki). 
temat: "Przyjaciele odchodzq"). Nie ma w niej metafizycznej grozy, lecz naturalny kres świadomości („wzrok się odwraca i słuch głuchnie”, Śmierć pospolita, s. 326), spowodowany błahą przyczyną: „nie los nie piorun ale owad” (s. 327). Ten naturalistyczny opis może być jednak mylny; jeśli bowiem nawet śmierć nie jest mroczną siłą z zaświatów, to i tak pozostaje niepojęta. Chory przyjaciel jeszcze przed chwilą oddychał, a Pan Cogito pomagał mu wygodniej ułożyć się na łóżku; tymczasem po krótkiej nieobecności, spowodowanej wyjściem na papierosa, „nie zastał już przyjaciela/ na jego miejscu/ leżało coś innego/ z przekrzywioną głową/ i wytrzeszczonymi oczami" (Pan Cogito obserwuje zmartego przyjaciela, s. 390). Obraz ten sugeruje, że gdyby nawet Cogito bez przerwy czuwał przy chorym, to i tak nie dostrzegłby metafizycznej zmiany, w wyniku której przyjaciel stał się martwym przedmiotem. $Z$ jednej strony śmierć należy do obserwowalnych procesów biologicznych, z drugiej - właśnie one powodują, iż nie możemy pojąć jej najgłębszej tajemnicy. Na poziomie zdarzeń fizycznych bowiem, związanych z unieruchomieniem ciała, które przestało oddychać oraz reagować na bodźce, nie daje się uchwycić nicości, która właśnie wtargnęła do świata. Przywołany wiersz sugeruje zatem, że śmierć ma strukturę złożoną, której tylko jedna z powierzchniowych warstw (obserwowalne zmysłowo zachowanie umierającego) jest nam poznawczo dostępna; to, co metafizyczne, pozostaje zakryte. Podobnie tajemniczą i skomplikowaną strukturę ma język; wprawdzie Horacy używa tej samej mowy co hycel, wobec czego nie należy poezji wyrywać „ze szponów/ codzienności”, jednak tylko poeta odkrywa głębię języka, który dzieli z hyclem (Pan Cogito. Ars longa, s. 660).

Spotkanie ze śmiercią to doświadczenie bezradności, umarłego nie ożywi wszak nawet krzyk matki, która „szarpie bezwładne imię” (Białe oczy, s. 14). Chociaż jednak śmierć bliskich jest dla nas okrutna, nie musi być złem dla umarłych, uwalniając ich od wrogów i udręk życia (Śmierć lwa). Widać to zwłaszcza w kontekście długiej agonii, kiedy to śmierć przynosi ulgę jak sen lub narkotyk (Brewiarz I); umieranie jest wszak doświadczeniem strasznym, jakby natura lubiła dręczyć tych, którzy przegrali walkę o życie (Ostatni atak. Mikotajowi, Pal).

Los zmarłego pozostaje ukryty, śmierć widzimy bowiem tylko z perspektywy żywych - jako odejście tam, dokąd wcześniej pospieszyli inni (Artur). Wprawdzie po umarłym zostają różne przedmioty, jak pióro, krzesło czy biurko, niekiedy także uczniowie lub parę książek trwalszych od spiżu (Do Henryka Elzenberga w stulecie Jego urodzin), jednak główne pytanie dotyczy świata, do którego dotarł, nie zaś tego, który opuścił. Zgodnie z Herbertowską ironią, brzmi ono zwyczajnie - „czy dostanę nowe mieszkanie” (Życiorys, z tomu Rovigo, s. 589)22 i wyraża niepewność, czy po śmierci czeka nas „złote runo

22 Wiersz można interpretować zarówno w duchu trosk codziennych (zdobycie mieszkania w czasach komunizmu graniczyło z cudem), jak i w perspektywie „naszej małej stabilizacji”, kiedy to telewizor, meble czy mały fiat (o nowym mieszkaniu nie wspominając) były szczytem marzeń. W wierszu Herberta obecny jest także wymiar eschatologiczny, związany z losem 
nicości” (Przestanie Pana Cogito, s. 439), czy też będziemy śpiewać w anielskich chórach, spowici „światłością niepojętą" (Artur, s. 485). Źródłem nadziei na nieśmiertelność może być niemożliwość pomyślenia własnego unicestwienia, którą poeta zobrazował żartobliwym wersem: „nie ma mnie i nie ma zupełna pustka” (Koniec, s. 652). Dosłownie wszak rozumiane wyrażenie „nie ma mnie" jest wewnętrznie sprzeczne; wprawdzie mogę stwierdzić, że nie ma mnie obecnie w Krakowie (skoro jestem w Szczecinie), to jednak trudno nadać jakikolwiek spójny sens wyrażeniu ogólnemu „nie ma mnie” (w sensie absolutnym, oznaczającym, że nie ma mnie nigdzie). Skoro jednak potrafię wypowiedzieć słowa „nie ma mnie”, to jest oczywiste, że nadal jestem obecny jako realny (istniejący i świadomy) podmiot, bezskutecznie usiłujący pomyśleć swoją totalną nieobecność. Niemożliwość realnego pomyślenia unicestwienia własnego ja była w dziejach filozofii uznawana za argument na rzecz nieśmiertelności (John Locke, Edmund Husserl), świadczy bowiem o tym, że nigdy nie zaistnieją warunki, w których podmiot będzie mógł stwierdzić, że jego własna śmierć była ostatecznym kresem jego istnienia ${ }^{23}$. Takiego stwierdzenia nie będzie też mógł nigdy wypowiedzieć obserwator zewnętrzny mojej śmierci, który - widząc moje zwłoki - nie będzie miał żadnych danych po temu, aby stwierdzić, że zostałem ostatecznie unicestwiony jako świadomy siebie podmiot. Rodząca się w ten sposób nadzieja na nieśmiertelność jest ważna szczególnie w wypadku śmierci zadanej przez łobuzów od historii (Pan od przyrody), czyli takiej, która - na pierwszy rzut oka - niczemu nie służy i niczego nie ocala.

Zgodnie ze scenariuszem zarysowanym w wierszu Chrzest, mamy przed sobą dwie możliwości - drogę w górę lub drogę w dól. Pierwsza prowadzi ku anielskiej doskonałości nieba ${ }^{24}$, druga może oznaczać zarówno rozkład w grobie, jak i pozostanie na ziemi w postaci żuka (Pan od przyrody) lub imienia wspominanego przez przyszłe pokolenia (Las Ardeński). $\mathrm{Z}$ jednej zatem strony istnieje możliwość osiagnnięcia życia wiecznego w nowym świecie, z drugiej - pozostania w obrębie świata doczesnego, który będzie miejscem dalszego trwania lub nicości.

po śmierci, który tych znaczeń codziennych nie przekreśla, lecz je dopełnia: „Tak jak inni chciałem wiedzieć co stanie się ze mną po śmierci/ czy dostanę nowe mieszkanie i czy życie ma sens”, s. 589). Można tu także widzieć przywiązanie ludzi do świata doczesnego, wobec czego nawet wieczność pojmują na jego wzór.

${ }^{23}$ Zygmunt Freud uważał, że niemożliwość pomyślenia własnego unicestwienia świadczy o tym, iż nieśmiertelność, którą rozumiemy intuicyjnie (instynktownie), jest pojęciem bardziej podstawowym od śmierci, której musimy się dopiero nauczyć w toku żmudnych doświadczeń, polegających na obserwacji umierania innych istot żywych.

${ }^{24}$ Według obliczeń Jadwigi Puzyniny, Herbert użył w swych wierszach wyrazu „nieba" aż 75 razy, przy czym tylko 3 razy na wskazanie miejsca przebywania Boga i zbawionych (Pan od przyrody, Brzeg oraz Rodzina Nepenthes). Pozostałe użycia mają charakter metaforyczny. Zob. J. Puzynina, Niebo Herberta, „Ethos” 2000, nr 4, s. 71-72. Nie podważając tych ustaleń, będę używał nazwy „niebo” na oznaczenie nie tyle miejsca przebywania zbawionych, ile specyficznej formy wiecznego istnienia po śmierci. Odniesienia do tak rozumianego nieba znajdują się w wielu wierszach Herberta. 


\section{Niebo}

W filozofii europejskiej istnieje silny nurt platoński, utożsamiający człowieka z niezniszczalną duszą, która w chwili śmierci ciała uwalnia się z więzów skończoności, istniejąc odtąd w postaci boskiej. Idea nieśmiertelności duszy jest również obecna w chrześcijaństwie, stanowiąc jeden z dogmatów Kościoła rzymskiego ${ }^{25}$. Wprawdzie łączy się tu z wiarą w zmartwychwstanie (wskrzeszenie) ciała, wyrażoną w Symbolu Apostolskim oraz credo nicejskim, to jednak ciało zmartwychwstałe - wzorowane na opisach epifanii Jezusa ma więcej cech duchowych niż fizycznych ${ }^{26}$. W takim zaś razie (wbrew znanej tezie Oskara Cullmanna) nie ma istotnej różnicy między nieśmiertelną duszą a wskrzeszonym ciałem; w obu wypadkach chodzi bowiem o transformację bytu śmiertelnego w nieśmiertelny. Różnicę tę ignoruje także Herbert, przekonując, że nie da się konsekwentnie oddzielić duszy od ciała, nawet bowiem w opisach nieśmiertelnej duszy używamy wyrażeń zmysłowych (Sprawozdanie $z$ raju ${ }^{27}$. Ważniejsze jest to, co oba modele łączy, niż to, co je dzieli; właściwą opozycją nie jest zatem (nieśmiertelna) dusza i (wskrzeszone) ciało, lecz to, co ludzkie i anielskie (boskie), ziemskie i niebiańskie.

Dopuszczając możliwość nieba, stajemy przed pytaniem, czy zbawiony będzie tą samą osobą, która żyła i umarła na ziemi. Rozwiązania tej kwestii były różne, podstaw tożsamości upatrywano bowiem $\mathrm{w}$ indywidualnej duszy, która nie ginie w chwili rozpadu ciała fizycznego (Platon), w jej dostosowaniu do konkretnego ciała, z którym zostanie ponownie złączona po zmartwychwstaniu (Tomasz z Akwinu) bądź też w Bożej wszechmocy, łatwiej wszak ożywić zmarłego, niż stworzyć go na nowo (Blaise Pascal). W tekstach Herberta nie ma jednak do tych obrazów żadnych odniesień; powodem nie jest sceptycyzm poety wobec filozoficznych spekulacji, lecz skupienie na pytaniu

${ }^{25}$ Dogmat został ustanowiony w 1513 roku przez Leona X, jednego z najbardziej zagorzałych platoników w dziejach chrześcijaństwa. Zob. W. Sady, Dzieje religii, filozofii i nauki. Od Pico della Mirandoli do Miguela Serveta, Kęty 2013, s. 26. U podstaw orzeczenia leżała chęć przeciwdziałaniu wpływom arystotelizmu, którego zwolennicy często przeczyli możliwości rozumowego dowodu na nieśmiertelność indywidualnej duszy.

${ }^{26}$ Zob. M. Szram, Ciato zmartwychwstate w myśli patrystycznej przetomu II i III wieku, Lublin 2010; Z. Kijas, Niebo w domu Ojca, czyściec dla kogo, piekto w oddaleniu, Kraków 2010.

${ }^{27}$ Opisane w tym wierszu budowanie doskonałego świata może oznaczać zarówno tworzenie społeczeństwa komunistycznego (i związaną z nią konieczność odstępstw od doktryny z uwagi na realia życia), jak i krytykę idei stworzenia człowieka przez Boga oraz czysto duchowych wizji zmartwychwstania. Dusza nieustanie łączy się „z kroplą sadła nitką mięśni”, a „niebiescy proletariusze/ pod pachą niosą niezgrabnie swe skrzydła jak skrzypce”; Boga jednak „oglądać będą nieliczni/ jest tylko dla tych z czystej pneumy". Ostatnie dwa wersy mogą wskazywać nie tylko na los człowieka, wykluczonego z nieba (zwłaszcza w świetle wcześniejszych słów: „tylko Jan to przewidział: zmartwychwstaniecie ciałem", s. 333), ale także na strukturę państwa komunistycznego, w którym przed oblicze władzy robotniczej dostają się jedynie najbardziej zaufani, wolni od wszystkich przywar burżuazyjnych. 
bardziej zasadniczym - czy transformacja bytu skończonego (ludzkiego, ziemskiego) w nieskończony (anielski, niebiański) będzie dla człowieka dobrem. Herbert odpowiada negatywnie, ponieważ przekształcenie ludzi w istoty doskonałe oznaczałoby zniszczenie ich natury; człowiek pozbawiony fizycznego ciała byłby wszak nowym stworzeniem, nie zaś tym, który żył i umarł na ziemi. Wprawdzie ten nowy byt byłby doskonalszy, to jednak stanowiłby tylko kopię oryginału, analogiczną do fresków w Heraklionie, gdzie jedyną pozostałością historyczną są „popękane zgrubienia o nieokreślonym kolorze”; wszystko inne jest „rekonstrukcją, domysłem, fantazją (...), jakby ktoś pomiędzy odnalezione członki starożytnego poematu wpisał słowa własne"28. Podobnie byłoby w niebie zbawionych, będących raczej aniołami niż ludźmi.

Herbert przekonuje, że taka nieśmiertelność jest nieludzka, wobec czego Pan Cogito będzie się przed nią bronić. Nawet, jeśli zostanie wysłany na czyśćcowy kurs kandydatów do raju (polegający na tępieniu ziemskich nawyków), będzie prosił o oszczędzenie mu niebiańskich rozkoszy i zgodę na powrót „przez zarosłą ścieżkę/ nad brzeg białego morza/ do groty początku" (Przeczucia eschatologiczne Pana Cogito, s. 476 ${ }^{29}$. Potwierdza to Sąd Ostateczny, na którym staje „całe beczące stado dwunogów” ( $U$ wrót doliny, s. 81), podobny do obozu koncentracyjnego, gdzie odziera się ludzi z ich indywidualności ${ }^{30}$. Strażnicy trzebią „ostatki zmysłów/ kandydatów do raju”, co potęguje obawę Pana Cogito, „że jest niezdolny/ do służby/ niebieskiej” (Przeczucia eschatologiczne Pana Cogito, s. 475-476). Jeśli jednak zostanie przekształcony w anioła („w zeschły płomyczek, który chodzi po ścieżkach wiatrów”, Żeby tylko nie aniot, s. 305), to podejmie bunt, niebo oznaczałoby bowiem dla niego utratę najcenniejszych wartości.

Zostając aniołem, Pan Cogito będzie cierpiał na nadmiar czasu, doświadczając monotonii i pustki, jak „chory na płuca” lub „cesarz na wygnaniu” (Przeczucia eschatologiczne Pana Cogito, s. 473). Opis ten nawiązuje do problemu nudy nieśmiertelności, dyskutowanego zarówno przez filozofów, jak i poetów, którzy sądzą, że wieczne istnienie, polegające na ciągłym przeżywaniu tych samych myśli czy wykonywaniu tych samych działań, musiałoby zrodzić pragnienie śmierci ${ }^{31}$. Herbert stawia tezę bardziej radykalną, ponieważ

28 Z. Herbert, Labirynt nad morzem, Warszawa 2000, s. 11.

${ }^{29}$ Wiersz ten można odczytać mniej dosłownie - jako metaforę budowy ustroju totalitarnego, mającego być rajem na ziemi. Zgodnie wszak z poglądem poety, żadna utopia nie jest skrojona na miarę człowieka; przeciwnie, to utopiści dostosowują ludzi do swych niebiańskich (czy raczej piekielnych) wizji. Również jednak dosłowna interpretacja wiersza, zgodna z jego tytułem, nie jest błędem. Zbieżność między utopiami społecznymi a religijną wizją raju polega nie tylko na używaniu kategorii sakralnych przez reformatorów, lecz także na tym, że religijne modele eschatologiczne bywają okrutne (piekło).

${ }^{30}$ Grozę „rekrutacji do nieba” dodatkowo wzmacnia język, przypominający głos sprawozdawcy, relacjonującego zawody sportowe lub pochód pierwszomajowy. Zob. S. Barańczak, dz. cyt., s. 101.

31 Zob. B. Williams, Sprawa Makropulos: refleksje nad nuda nieśmiertelności, thum. T. Duliński [w:] tegoż, Ile wolności powinna mieć wola? i inne eseje z filozofii moralnej, tłum. T. Baszniak, T. Duliński, M. Szczubiałka, Warszawa 1999, s. 65-87; J.L. Borges, Nieśmiertelność, tłum. 
nawet nieśmiertelnym bogom, cieszącym się pełnią istnienia, przypisuje bezruch i potężne ziewanie (Pan Cogito a dtugowiecznośc). Chociaż w takiej opinii można upatrywać deprecjonowania bogów $w^{32}$, to jednak jest ona także krytyką idei zbawienia, polegającego na wielbieniu Boga za pomocą „mamrotania dwuwymiarowych chórów" (Żeby tylko nie aniot, s. 305). Poeta wyraża w ten sposób obawę przed istnieniem, które nie jest skrojone na ludzką miarę. Poznanie pełnej prawdy mogłoby nas oślepić, każda wszak percepcja wymaga zajęcia określonego punktu widzenia; tymczasem w niebie prawda byłaby dana w całości, bez żadnej perspektywy (Raj teologów), co może być właściwe aniołom, okazuje się jednak zgubne dla ludzi ${ }^{33}$.

Równie trudno wyrzec się ziemskiego ciała (Przeczucia eschatologiczne Pana Cogito); chociaż czujemy się w nim skrępowani (Higiena duszy), to jednak tylko ono łączy nas ze światem. Człowiek bowiem to nie dusza, frunąca ku niebu jak Ikar, lecz żywa plazma, mająca „dwoje rąk do zasłaniania głowy”, „dwoje nóg szybkich w ucieczce”, a także „zdolność oddychania”, „zdobywania pokarmu” i „przekazywania życia pod murem więziennym” (Substancja, s. 160). Zredukowany do anioła, Pan Cogito przypominałby zmarłych leżących w grobie, mających usta pełne piasku i niezdolnych wydobyć głosu. Jego nieśmiertelność byłaby zatem równie fikcyjna, jak trwanie zakonserwowanego szkieletu, sprzedanego akademii (Do moich kości).

Jeszcze większą grozę budzi w Panu Cogito samotność zbawionych, przyjmowanych do nieba pojedynczo. Na Sądzie Ostatecznym słychać rozdzierający „krzyk matek od których odłączają dzieci” ( $U$ wrót doliny, s. 81), a można też zobaczyć zrozpaczoną staruszkę, która „niesie/ zwłoki kanarka”, ponieważ „był taki miły” i „wszystko rozumiał”, lub drwala ściskającego siekierę, która żywiła go na ziemi ( $U$ wrót doliny, s. 82). Równie smutna będzie wieczność poety - „bez podróży/ przyjaciół/ książek” oraz „pióra/ inkaustu/ pergaminu” (Przeczucia eschatologiczne Pana Cogito, s. 473) ${ }^{34}$. Wprawdzie ludzie łudzą się, że ukryją przed okiem strażników „strzępy listów wstążki włosy ucięte/ i fotografie", to jednak przemycenie do nieba choćby skrawka tego, co ziemskie, jest wykluczone ( $U$ wrót doliny, s. 83).

Obraz ten można uznać za polemikę z nauką Jezusa, głoszącą, że „po zmartwychwstaniu ludzie nie będą się żenić ani za mąż wychodzić, lecz będą jak

D. Walasek-Elbanowska, „Literatura na Świecie” 1988, nr 12, s. 45-54; J.L. Borges, Niémiertelny, tłum. M. Potok-Nycz [w:] tegoż, Alef, ttum. Z. Chądzyńska, M. Potok-Nycz, Warszawa 2003, s. 5-27.

${ }^{32}$ Zob. S. Barańczak, dz. cyt., s. 69.

33 Percepcja zakłada selekcję danych, bez której przerodziłaby się w chaos wrażeń, uniemożliwiający dostrzeżenie przedmiotu. Analogicznie jest z pamięcią, która - pozbawiona selekcji - byłaby dla człowieka bezużyteczna, a nawet zabójcza, co zilustrował Borges w opowiadaniu Pamiętliwy Funes.

${ }^{34}$ Trudno się zatem dziwić, że nieśmiertelność przerażała Pana Cogito od dzieciństwa (Pan Cogito a dtugowiecznośc) ). 
aniołowie w niebie" (Mt 22, 30) ${ }^{35}$. Na przekór takim twierdzeniom poeta mówi, że nawet w niebie istnieją cenniejsze wartości niż oglądanie Boga ${ }^{36}$, człowiek nie został bowiem stworzony do rozkoszy niebiańskiego raju, lecz do życia na ziemi; jeśli zaś stwórca przeznaczył nas do wieczności, to musi ona być stosowna do naszej natury. Jak zatem Rainer Maria Rilke prosił o śmierć własną, co wynika z życia (Księga godzin), tak Herbert prosi o wieczność własną, co wynika z życia. Lepiej bowiem „wstąpić w kamień, w drzewo, w wodę, w szpary furty" (Źeby tylko nie aniot, s. 305) niż do nieba, gdzie czeka nas martwota doskonałości ${ }^{37}$; właściwsze jest zatem dla nas pozostać „skrzypieniem podłogi”, po której stąpają nasi bliscy, niż stać się „przeraźliwie przeźroczystą doskonałością” (Żeby tylko nie aniot, s. 305). Wprawdzie w niebie przechadzalibyśmy się wśród starannie przyciętych drzew, mijając „kamienne symbole cnót, czyste jakości, idee przedmiotów i wiele innych rzeczy zupełnie niewyobrażalnych" (Raj teologów, s. 182), byłby to jednak świat nieludzki ${ }^{38}$. Tezę tę dobrze ilustrują środki poetyckie, stosowane przez Herberta; symbolami doskonałości są wszak w jego wierszach biel i jasnośćc ${ }^{39}$, co odpowiada biblijnej symbolice nieba ${ }^{40}$. Ponieważ jednak biel jest również symbolem bezruchu, śmierci i milczenia ${ }^{41}$, prawdziwe oblicze człowieka jako istoty ziemskiej i ułomnej ukazuje szarość - ulubiony kolor poety ${ }^{42}$. Sugeruje to, że Pan Cogito nie mieszka ani w doczesnej arkadii utopistów, ani w niebiańskim raju teologów ${ }^{43}$. Jeśli zaś nawet spróbuje powtórzyć wyczyn Ikara, nierozumiejącego, że skrzydła są tylko przenośnią, runie w dół (Dedal i Ikar), człowiek jest bowiem przytwierdzony do ziemi ${ }^{44}$.

${ }^{35}$ Cytuję przekład pod redakcją ks. Mariana Wolniewicza.

36 Podobny wydźwięk ma wiersz Bolesława Leśmiana Urszula Kochanowska.

37 Zob. S. Barańczak, dz. cyt., s. 52, 62-63.

38 Zob. tamże, s. 61.

39 Zob. tamże, s. 49-50.

40 Zbawieni są odziani w białe szaty, które wybielili w krwi Chrystusa (Ap 7, 9-14).

${ }^{41}$ Zob. S. Barańczak, dz. cyt., s. 47.

${ }^{42}$ Zob. tamże, s. 49, 65; K. Dybciak, dz. cyt., s.159.

${ }^{43}$ Zob. S. Barańczak, dz. cyt., s. 127. Wyrazem lęku przed doskonałością jest także wiersz W pracowni, w którym poeta poddaje krytyce stworzony przez Boga świat; właśnie dlatego, że jest on doskonały, nie da się w nim mieszkać. Świat malarza („pełen pomyłek”, chociaż zarazem pełen kolorytu) jest nam bliższy niż twór boskiego zegarmistrza, zbudowany według miary, liczby i wagi. W tej sytuacji trudno się zgodzić z opinią, że Herbert uważał człowieka za istotę, która pragnie powrotu do utraconego raju (o czym ma świadczyć wiersz Książka z tomu Rovigo). Zob. M. Dzień, Bogowie Herberta, „Teksty Drugie” 2000, nr 3, s. 166. Wbrew tej pesymistycznej wykładni utratę raju można uznać za nasze właściwe narodziny, polegające na odkryciu tego, kim jesteśmy.

${ }_{44}$ Zob. S. Barańczak, dz. cyt., s. 53, 257. Podobny jest los księdza, który - celebrując nabożeństwo - zbliża się do Boga po stopniach ołtarza; ten akt transcendencji nie trwa jednak długo, wstąpiwszy bowiem „na dwa pierwsze stopnie” kapłan „ślizga się w dół/ jak mucha” (Ostatnia prośba, s. 257). Dużo bardziej dramatyczny jest inny obraz (Przestuchanie anioła), w którym Herbert demaskuje nasze iluzje; człowiek prowadzony na tortury - wiedząc, że jest niewinny - wierzy $\mathrm{w}$ triumf prawa i sprawiedliwości, po chwili zostaje jednak zamieniony w krwawiący zwał mięsa. 
Herbertowski opis nieba podważa tradycyjny podział „na zgrzytających zębami/ i śpiewających psalmy" ( $U$ wrót doliny). Skoro bowiem zbawieni zostali ograbieni ze wszystkiego, co było im drogie, to cierpią podobnie do tych, którzy znaleźli się w piekle. W ten sposób niebo zostało skompromitowane ${ }^{45}$, z jednej bowiem strony jest lodowatą doskonałością, o czym świadczą „kamienne sy bole cnót” (Raj teologów) ${ }^{46}$, z drugiej bywa nadmiernie „przesłodzone” (Homilia), duszpasterze bowiem lukrują rzeczywistość, analogicznie do ozdabiaczy, sztukatorów czy poetów, zainteresowanych nie prawdą, lecz powierzchowną pociechą, rodzącą u odbiorcy uśmiech i radość (Ornamentatorzy). W tej sytuacji można dojść do wniosku, że bardziej atrakcyjną formą wieczności będzie piekło. Choć jest ono stanem rozpaczy (człowiek wstydzi się wyjść na ulicę z pogryzionymi wargami i w rozlatujących się butach) oraz bezskutecznym czekaniem na zbawienie (kelner nigdy nie przyniesie kawy ani oranżady), to zakochani mogą się jednak łudzić, że będą zawsze razem, czego nie zmieni nawet rechot diabła za kotarą (Piekto) ${ }^{47}$. Skoro zaś zbawienie dokonuje się pojedynczo, to lepiej być $\mathrm{w}$ piekle $\mathrm{z}$ innymi niż w niebie - samemu. W ten sposób podważony zostaje także etyczny sens zaświatów, trudno bowiem niebo uznać za nagrodę dla szlachetnych, a piekło za karę dla niegodziwców.

Wniosek ten nie znaczy, że Herbert wątpił w miłosierdzie Boga ${ }^{48}$; skoro bowiem stwórca przygotował dla nas rajską doskonałość, to nie należy go po-

${ }^{45}$ Zob. S. Barańczak, dz. cyt., s. 101.

${ }^{46} \mathrm{Z}$ racji roli figury kamienia w poezji Herberta interesujące byłoby zestawienie takiego obraz raju z tomem opowiadań Tadeusza Borowskiego Kamienny świat.

${ }^{47}$ Tekst ten można odczytać także bardziej dosłownie, jako opis życia w mieście, gdzie stłoczeni w blokowiskach ludzie żyją w izolacji.

${ }^{48}$ Zdaniem Kopcińskiego świadectwem zwątpienia poety w miłosierdzie Boga jest monolog Sokratesa z dramatu Jaskinia filozofów. Zob. J. Kopciński, dz. cyt., s. 203-204. Innymi przykładami rozczarowania Herberta Bogiem ma być wiersz Gwóźdź w niebie bądź Wąwóz Matachowskiego, którego bohater na próżno przyzywał pomocy nieba. Zob. J. Puzynina, dz. cyt., s. 76-79. Także metafora gwiazdy (pojawiająca się w jego poezji 49 razy) czy obłoków (do której odwołał się 30 razy) ma dowodzić, że Bóg nie interesuje się człowiekiem. Zob. tamże, s. 79, 24. Problem jest szerszy, dotyczy bowiem także możliwości (czy raczej - niemożliwości) wiary w Boga po Holokauście; odtąd niebo mówi do nas „obcą mową” (Do Marka Aurelego). Zob. J. Kornhauser, dz. cyt., s. 23. Z kolei w wierszu bez tytułu, dedykowanym Barbarze Toruńczyk (opublikowanym w 68 numerze „Zeszytów Literackich”), Herbert ukazuje świat oczyma dziecka, co jeszcze bardziej obciąża Boga za zło, wykluczając możliwość wybaczenia Mu okrucieństwa dziejów. Zob. M. Cyranowicz, Herbertowskie inedita, „Ethos” 2000, nr 4, s. 219-220. Garbol uważa z kolei, że nieludzkim obrazom nieba Herbert przeciwstawia Chrystusa jako bliskiego Boga. Zob. T. Garbol, Kilka czystych taktów, „Ethos” 2000, nr 4, s. 95. Wykładnia ta jest jednak wątpliwa; zdecydowanie trafniej problem Chrystusa w poezji Herberta ujmuje Wojciech Bonowicz, analizując wiersz Postój. Wprawdzie w scenerii utworu wyczuwa się obecność Ukrzyżowanego, to jednak nie ma Zmartwychwstałego, wobec czego uczta jest jedynie stypą (lub posiłkiem po ciężkiej pracy katów), w której trudno dopatrzeć się Eucharystii. Zob. W. Bonowicz, Otwarcie wiersza [w:] Poeci czytaja Herberta, dz. cyt., s. 29-39. Jeszcze inną kwestią jest to, czy Herbert wierzył w Chrystusa; na takie pytanie zdecydowanie twierdząco odpowiada Jan Sochoń. Zob. J. Sochoń, Bóg poety, „Ethos” 2000, nr 4, s. 120-125. 
dejrzewać o złą wolę. Błędem Boga jest jedynie to, że ofiarował nam zbyt wiele, ignorując ograniczenia naszej natury; wprawdzie chciał ludziom dać to, co najlepsze, nie przewidział jednak, że w ten sposób skaże ich na cierpienie. Przypomina zatem rodzica, który odebrał dziecku ukochaną zabawkę, ponieważ była stara, zniszczona i brudna, w zamian zaś kupił nową, której dziecko nie chciało i którą nie umie się bawić. Podobnie Stwórca przygotował nam luksusowy pałac w niebie, nie rozumiejąc, że lepiej czujemy się w skromnym mieszkaniu ziemskim; nie brakuje mu zatem miłosierdzia, a jedynie wszechwiedzy. $Z$ punktu widzenia klasycznego teizmu znaczyłoby to, że w ogóle nie jest Bogiem; z perspektywy poezji Herberta dzieje się jednak inaczej, ponieważ najdoskonalszy („najpiękniejszy”) okazuje się przedmiot, którego nie ma (Studium przedmiotu). Poeta ironicznie odnosi się do klasycznej idei filozoficznej, najpełniej wyrażonej przez Gottfrieda Wilhelma Leibniza, w myśl której racją istnienia jest doskonałość; prawda okazuje się tymczasem odwrotna doskonałość wyklucza możliwość istnienia. Wniosek ten może przywrócić nadzieję Panu Cogito; skoro bowiem istnieją tylko rzeczy niedoskonałe, to nawet niebo musi mieć usterki, które uczynią je możliwym do zniesienia ${ }^{49}$. Wprawdzie człowiek wielbi „rzeczy trwałe/ prawie nieśmiertelne” (Pana Cogito przygody z muzyka, s. 564), wybiera jednak „to co podlega/ ziemskim miarom i sądom". W ten sposób, opowiadając się za niebem jako przedłużeniem ziemi (Pan od przyrody), Pan Cogito odrzuca ideę wieczności jako przebóstwienia; wybiera drogę w dół.

\section{Ziemia}

Nieśmiertelność ziemska ma różne formy; jedną z nich jest panteistyczne rozpłynięcie się w materii wszechświata. Taka wieczność nie różniłaby się jednak od nicości (Wersety panteisty), ponieważ z chwilą śmierci znika jaźń, a ciało ulega rozproszeniu. Mimo iż proces ten nie oznacza kresu istnienia, lecz jedynie zmianę ${ }^{50}$, to jednak człowiek zostaje zredukowany do stanu martwych rzeczy $(\text { Umarli })^{51}$.

Inną formą nieśmiertelności ziemskiej jest reinkarnacja, budząca nadzieję na to, że zmarłych można spotkać w postaci „żuka który gramoli się/ na kopiec piasku" (Pan od przyrody, s. 122). Obraz ten może świadczyć zarówno o możliwości kolejnych wcieleń po śmierci (także w organizmy niebędące

${ }^{49}$ Podobnie jest z systemami totalitarnymi, w których daje się żyć tylko dlatego, że nie osiągnęły perfekcji.

${ }^{50}$ Zob. J. Gutorow, Herbert, pies i gwiazda [w:] Poeci czytaja Herberta, dz. cyt., s. 68.

51 Pomijam problem, w jakim stopniu również rzeczy w świecie Herberta są zdolne do odczuwania emocji; człowiek jest wszak w tej poezji jedynie „elementem pejzażu, obok kamieni, traw, drzew, zwierząt dużych i małych”. Tamże, s. 67. 
ludźmi), jak i o nadziei, że nieśmiertelność (w jakiejkolwiek formie nas spotka) będzie intensyfikacją wartości, które ceniliśmy na ziemi. Ten zatem, kto umiłował badania nad przyrodą w życiu doczesnym, może marzyć o przeniknięciu jej tajemnic w życiu przyszłym; przy takiej interpretacji żuk z wiersza Pan od przyrody byłby nie tyle inkarnacją człowieka, ile symbolem dalszego trwania wartości, którymi zmarły żył na ziemi. Jeśli taka wykładnia jest dopuszczalna, to można uznać, że badacz przyrody już na ziemi doznał rozmaitych chwil wieczności, w czasie których udało mu się rozpoznać jakąś tajemnicę istot żywych (chociażby form życia i zachowania żuków). Takie momenty olśnienia, znane zarówno uczonym, odkrywającym nowe prawdy, jak i ludziom religijnym, mającym poczucie zjednoczenia z przedmiotem kultu czy artystom, odkrywającym piękno, mogą świadczyć, że wieczność nie zaczyna się dopiero po śmierci, lecz ma miejsce już w życiu ziemskim, w chwilach silnych wzruszeń, w których tracimy poczucie przemijania.

Przykładem takich chwil wieczności (zatrzymania czasu) są w poezji Herberta epifanie, polegające bądź to na doznaniu rozkoszy lub smutku, bądź też na objawieniu transcendencji, dostępnej w akcie kontemplacji ${ }^{52}$. Jak bowiem przekonuje Herbert w Przypowieści o królu Midasie, człowiek jest istotą zbudowaną ,z krwi i złudy”, zdolną do rozkoszowania się pięknem. Świadczy o tym malarz waz, który utrwala życie cieni ${ }^{53}$, wobec czego każdy, kto będzie je oglądać, dozna olśnienia, będącego chwilą wieczności. Wprawdzie malarz jest śmiertelny, a waza krucha, jednak piękno wydaje się wieczne.

Wbrew temu optymizmowi Herbert podkreśla, że sztuka nikogo nie zbawia (Izydora Duncan) ${ }^{54}$, samo zaś dążenie do piękna kończy się klęską. Chociaż poeta „na pustyni stołu” stara się stworzyć nowe słowo, to jednak ostatecznie musi przyznać, że „nie udało się/wniebowstąpienie” (Pisanie) ${ }^{55}$. Podobnie jego dzieła, zbudowane $\mathrm{z}$ atramentu, nie mogą być wieczne (Nic tadnego); są jednak zapisem chwili, której nie zniszczy ani upływ czasu, ani śmierćs6. W duchu Rozmyślań Marka Aureliusza Herbert sugeruje zatem, że ten, kto

52 Zob. B. Shallcross, Zbigniewa Herberta podróż do zachwytu, „Teksty Drugie” 2000, nr 3, s. 61. Epifanie te przypominają nietzscheańską ideę „okamgnienia”.

53 Określenie to nawiązuje do platońskiej teorii idei oraz świata materialnego jako cienia bytu, czego jednak nie będę rozwijać.

${ }^{44}$ Tezę, że piękno nie zbawia, rozwijał Józef Tischner, podkreślając w ten sposób różnicę między filozofią grecką a chrześcijaństwem, proklamującym zbawienie przez dobro. Zob. J. Tischner, Myślenie w żywiole piękna, wybór, oprac. W. Bonowicz, Kraków 2005. Podobnie argumentował kardynał Carlo Martini, używając nieco innego języka; jego zdaniem piękno zbawia, nie jest to jednak piękno sztuki, lecz piękno Boga i Ewangelii. Zob. C.M. Martini, Jakie piękno zbawi świat?, tłum. Z. Zwolska, „Ethos” 2000, nr 4, s. 19-35.

55 Wiersz ten ma wiele dodatkowych znaczeń, związanych zarówno z ironicznym stosunkiem do innych poetów, jak i z autoironią Herberta wobec twórczości własnej.

${ }^{56}$ Jeden z ulubionych malarzy Herberta, Gerard Terborch, uważał podobnie, że zadaniem artysty jest utrwalenie pięknego pozoru rzeczy. Według Herberta jest ono równoważne zatrzymaniu (uwiecznieniu) chwili. Zob. P. Siemaszko, dz. cyt., s. 178. 
przeżył chwilę wieczności na ziemi, nie musi marzyć o dalszym życiu w innym świecie. Tak samo bowiem, jak w jednym dniu życia dana jest cała jego treść (głód, sytość, smutek, radość, cierpienie, ulga, nadzieja, rozpacz, lęk, ukojenie), tak również w chwilowej iluzji wyzwolenia z czasu można doświadczyć wieczności. Nieszczęściem ludzi nie jest zatem to, że innego życia nie będzie, lecz to, że doczesne chwile wieczności częściej wiążą się z cierpieniem niż z rozkoszą; obok rozumu przecież Pan Cogito ma też ciało, zdolne odczuwać ból i lęk. W tej sytuacji prawdziwe szczęście polega na wyzbyciu się złudzeń (Pożegnanie). Wprawdzie na łożu śmierci może nam dokuczać nadzieja, że „potem wrócimy” (Modlitwa starców), powrót ów jednak będzie możliwy tylko we wspomnieniach ludzi, którzy nas przeżyją. Jedyna zatem nieśmiertelność nam dostępna to pamięć przyszłych pokoleń.

Idea ta sięga antyku, jak bowiem uczą greckie mity, Achilles wybrał krótkie życie, opromienione wieczną sławą, zamiast życia długiego, którego nikt nie zapamięta. Nieśmiertelność ta ma jednak charakter zastępczy (trwałe są tylko imiona, dzieła i czyny) oraz elitarny (tylko nieliczni będą pamiętani). Opinię tę podziela również Herbert, sugerując, że spośród poetów wieku XX jedynie Rilke, T.S. Eliot oraz „kilku innych dostojnych szamanów” znajdzie się w panteonie nieśmiertelnych (Do Ryszarda Krynickiego - list). Bardziej dramatyczne jest jednak to, że w czeluściach historii giną bezimienne ofiary przemocy $(\text { Babcia })^{57}$. W opozycji do Miłosza, który gotów był sądzić, że ratunkiem dla ludzkości będzie zapomnienie (rozmowę umarłych należy zostawić umarłym), Herbert wręcz obsesyjnie podkreśla obowiązek kultywowania pamięci o zabitych ${ }^{58}$.

Polegli są nadal obecni ${ }^{59}$ - zarówno w rzeczach, które po nich ocalały $(G u z i k i)^{60}$, jak i w bohaterskich czynach, których dokonali. Ponieważ jednak milczą o nich podręczniki historii, ocalenie pamięci staje się obowiązkiem każdego, kto przeżył (Trzy wierze zpamięci, Wilki, Pan Cogito o potrzebie ścistości) ${ }^{61}$. Sami zabici proszą nas zresztą „o wodę wspomnień” (Las Ardeński, s. 42), „o pagórek pulchnej ziemi/ o nikły znak znad powierzchni” (Cmentarz warszawski, s. 38). Wbrew Kainowi musimy być stróżami swych braci (Pan Cogito o potrzebie ścistości), ich krew woła bowiem tak samo, jak krew Abla. Nasza pamięć jest

57 Wiersz ten jest poświęcony babci Herberta, będącej pochodzenia ormiańskiego i pamiętającej ludobójstwo dokonane na Ormianach.

${ }_{58}$ Zob. Z. Najder, Ojczyzna i naród w poezji Zbigniewa Herberta, „Ethos” 2000, nr 4, s. $141,144$.

59 „Oni zostawili ślad, "nie umarli cali«, są obecni wszędzie. Ich szept słychać codziennie. Ten szept jest przerażający”. J. Kornhauser, dz. cyt., s. 25.

${ }^{60}$ Guziki są niekiedy jedynym śladem po ofiarach, stając się symbolem pamięci o nich. Zdecydowanie inny sens mają guziki z wiersza Pożegnanie września, będącego szyderstwem ze znanych słów marszałka Rydza-Śmigłego, iż nie oddamy nawet guzika.

${ }^{61}$ Zob. Z. Najder, dz. cyt., s. 141. 
nie tylko przymierzem z nimi ${ }^{62}$, lecz także zwycięstwem nad śmiercią; nawet, jeśli nie oznacza wskrzeszenia, to jednak chroni przed wymazaniem ich imion z dziejów. Zgodnie wszak z przesłaniem Raportu z oblężonego Miasta, wystarczy jeden, który pamięta, aby przeszłość ocalić. Wprawdzie trudno ustalić imiona oraz dokładną liczbę ofiar ('świadkowie ją zawyżają, oprawcy pomniejszają, a historycy operują haniebnym słowem „około”), to jednak w tym rachunku nie wolno się pomylić nawet o jednego (Pan Cogito o potrzebie ścistości).

Relacje z umarłymi komplikują się dodatkowo przez to, że ci, którzy odeszli, nadal troszczą się o nasz los: „napominają przez sen/ odnoszą zgubione pieniądze/ starają się nam o posadę/ szepczą numery losów" (Co robia nasi umarli). Niekiedy są nam bliżsi od żyjących, podtrzymują nas bowiem na duchu i nie wchodzą w konflikty. Pełnią także funkcję osądzającego nas sumienia, wobec czego - chociaż nie jesteśmy święci - staramy się dotrzymać im kroku; gdyby zatem ich zabrakło, spadlibyśmy „na dno/ opuszczenia” (Pan Cogito na zadany temat: "Przyjaciele odchodzą). Umarli potrafią także skarcić, chociażby za to, że zbytnio się na nich wykosztowujemy; byłoby lepiej, gdybyśmy - zamiast kupowania drogiej trumny, płyty nagrobnej czy kwiatów - dali pieniądze biednym (Co robiq nasi umarli). Dowodzi to, że nastąpiło odwrócenie ról - to nie my pamiętamy o zmarłych, lecz oni pamiętają o nas, stając się naszymi opiekuńczymi duchami. Nieśmiertelność w pamięci jest zatem paradoksalna, ponieważ to bardziej żyjący potrzebują opieki umarłych niż umarli troski żyjących. Ponieważ jednak jesteśmy zamknięci w sferze wąsko pojętej empirii i rozumu, nie rozpoznajemy znaków, za pomocą których do nas przemawiają; ich stukania $\mathrm{w}$ okno nie uważamy za głos z zaświatów, lecz za naturalny odgłos zbłąkanego owada lub liścia. Ślepi na ich znaki, wymyślamy zmarłym „nieśmiertelnośćl zaciszną jak norka myszy” (Co robia nasi umarli). Podobnie skrywamy bohaterów pod marmurową płytą, chociaż jest ona bardziej narzędziem izolacji niż symbolem pamięci (Cmentarz warszawski). Wracamy w ten sposób do praktyk ludzi pierwotnych, którzy - bojąc się zmarłych - chcieli uniemożliwić im powrót na ziemię.

Nie znaczy to, że świadomie i celowo usuwamy zmarłych ze świata; nie chcemy jednak stracić nad nimi kontroli, wobec czego wyznaczamy im miejsca zgodne $\mathrm{z}$ naszymi interesami. W ten sposób zmarli zostają uprzedmiotowieni, sprowadzeni do roli rzeczników lub świadków naszych sporów, niczym bezbronne i dyspozycyjne widma, „które zawsze przychodzą na umówione spotkanie" (In memoriam Nagy László). Herbert ilustruje w ten sposób znaną tezę Jeana Paula Sartre'a, że śmierć oznacza radykalne uprzedmiotowienie człowieka, czyni go bowiem zupełnie bezbronnym wobec tych, którzy pozostali przy życiu. Zmarlych nie wspominamy takimi, jakimi byli, lecz takimi, jakimi dzisiaj chcemy ich widzieć. W takim zaś razie również nieśmiertelność w pamięci

${ }^{62}$ Zob. E. Hirsch, Chlust zimnej wody, tłum. M. Heydel [w:] Poeci czytaja Herberta, dz. cyt., s. 106-107. 
pokoleń jest fikcją - im nachalniej zwracamy się ku przeszłości, tym bardziej przykrywamy ją kolejnymi warstwami zapomnienia ${ }^{63}$. Podobnie próby zawłaszczenia zmarłych powodują, że stają się oni jakby bardziej umarli, analogicznie do słów, które tracą znaczenie z chwilą wprzęgnięcia ich w machinę kłamstwa ${ }^{64}$.

Doszliśmy w ten sposób do kwestii śmierci języka, opisanej przez Herberta w krótkiej prozie poetyckiej Epizod w bibliotece. Jej tematem jest lament poległego poety, który został zredukowany do salamandry objedzonej przez mrówki. Dopóki żył, dopóty mógł się łudzić, że zmartwychwstanie w swych słowach; tymczasem analiza jego wierszy za pomocą kresek, polegająca na poszukiwaniu nie lamentu poety, lecz rytmu, akcentów i cezur, może sugerować, że nie istnieje granica rozkładu kultury (podobnie, jak nie ma granicy rozkładu ciała w grobie). Choć w czasach wielkich kryzysów dziejowych (takich jak wojna światowa czy ludobójcza rewolucja) może się wydawać, że ludzkość osiągnęła stan ostatecznego upadku, to jednak przyszłość pokazuje, że wojny mogą być jeszcze bardziej bezwzględne, a ludobójstwo zakrojone na zdecydowanie szerszą skalę. Przywołany tekst Herberta nie ogranicza się jednak do krytyki określonej metodologii badawczej, skupionej na formalnej strukturze poezji ani do opisu kryzysu wartości, charakterystycznego dla jakiejś epoki; jest także opisem śmierci języka, spowodowanej zerwaniem ciągłości doświadczeń. Znaczy to, że słowa, których używały dawne pokolenia, dla nas nie są w ogóle słowami, wobec czego zmarły poeta nie będzie żyć w swoich utworach $^{65}$. Wprawdzie Epizod można odczytywać optymistycznie (ostatecznej zagłady uniknie akcent lub litera ${ }^{66}$ ), ale trudno $z$ samych kresek złożyć na powrót sensowną całość, a tym bardziej usłyszeć w nich płacz zmarłego poety ${ }^{67}$.

Wiara w nieśmiertelność na ziemi okazuje się równie naiwna, jak wiara $\mathrm{w}$ niebo; $\mathrm{z}$ jednej bowiem strony czeka nas nieodwracalne rozproszenie ciała w materii kosmosu, z drugiej - zapomnienie naszych imion, dokonań (i słów) przez przyszłe pokolenia. Przesłanie poety okazuje się pesymistyczne; wprawdzie jest cudem to, że pojawiliśmy się na świecie, jednak nie jesteśmy w nim na stałe. Wobec tego - zgodnie z radami Marka Aureliusza, jednego z ulubionych myślicieli Herberta - powinniśmy być gotowi zarówno na rychły kres życia, jak i na ostateczne zapomnienie ${ }^{68}$. Wniosek ten podpowiada, że z dwu możliwych dróg - drogi w górę i drogi w dół - rzeczywista jest

${ }^{63}$ Zob. J. Kornhauser, dz. cyt., s. 25.

${ }^{64}$ Zob. K. Dybciak, dz. cyt., s. 147.

65 Zob. B. Maj, Mój prywatny epizod [w:] Poeci czytają Herberta, dz. cyt., s. 53.

${ }^{66}$ Zob. A. Franaszek, Wstęp [w:] Poeci czytaja Herberta, dz. cyt., s. 7.

${ }^{67}$ Tę pesymistyczną wykładnię zdaje się potwierdzać sam Herbert: „Pozostaną po nas w czarnej ziemi rozrzucone głoski. Akcenty nad nicością i prochem” (Epizod w bibliotece, s. 179). Pomijam w tej chwili podobieństwo tych zdań do zakończenia Pieśni Tadeusza Borowskiego: „Zostanie po nas złom żelazny/ i głuchy, drwiący śmiech pokoleń”.

${ }^{68}$ Zob. Marek Aureliusz, Rozmyślania, tłum. M. Reiter, Warszawa 1984: „(...) pamiętaj o tym, że w najbliższym czasie (...) pomrzecie. A wkrótce nie pozostanie śladu nawet z imion 
tylko ta druga, wobec czego życie ludzkie okazuje się wyprawą po „złote runo nicości”"69. Nieprzypadkowo zatem - obok Hektora i Rolanda - w Przestaniu Pana Cogito pojawia się Gilgamesz; ten mityczny bohater bowiem, pomimo olbrzymich przeszkód, zdobył ziele nieśmiertelności po to tylko, by od razu je stracić. Chociaż jednak odtąd nie możemy już mieć nadziei na wieczne życie, to nie musimy również swego losu przeklinać; w obliczu wszak ziemskich klęsk i cierpień śmierć może być ulgą (Pal).

\section{Niepewność i udręka}

Nakreślony obraz nie jest jeszcze kompletny, chociaż bowiem jedni wybrali drogę $\mathrm{w}$ górę, inni zaś drogę $\mathrm{w}$ dół, to jednak są również ludzie niezdolni wejść na żadną z nich. Wprawdzie nikt, kto podążył drogą w górę lub w dół, nie może wiedzieć, czy dokonał słusznego wyboru, to jednak ma prawo ufać, że otrzyma nagrodę stosowną do swych oczekiwań; niezdecydowani natomiast, nie potrafiąc dokonać wyboru, męczą są ciągłą niepewnością. Niezależnie zatem od tego, czy rację mają ci, którzy pokładają nadzieję w niebie, czy też ludzie pragnący ostatecznej śmierci, jednych i drugich „pogodzi nicośćl lub miłosierdzie”; sceptycy jednak, „przyjąwszy chrzest ziemi”, skazani są na udrękę wątpienia (Chrzest, s. 80). Nie należąc ani do kościoła żarliwych wyznawców, ani do kościoła bluźnierców, mogą się spodziewać strasznego losu - ciągłego zawieszenia między nicością a niebem.

Nie ma wątpliwości, że sceptyków Herbert traktuje z sympatią; potwierdzeniem jest nie tylko emocjonalny ton wiersza Chrzest, lecz także figura Pana Cogito. W przeciwieństwie do swych kartezjańskich źródeł herbertowskie Cogito nie jest żadnym eksperymentem myślowym, mającym pomóc przezwyciężyć zwątpienie przez odkrycie niepodważalnego fundamentu wiedzy. Przeciwnie, sympatyczny bohater Herberta (czasami budzący politowanie z powodu swej naiwności) okazuje się w rzeczywistości Panem Dubito, niezdolnym do przezwyciężenia swego sceptycyzmu. Bliższy raczej mędrcom starożytnym niż filozofom nowożytnym, poszukującym absolutnej pewności,

waszych” (IV, 6). „Wszystko jednodniowe: i co wspomina, i co jest wspomniane” (IV, 35). „Wnet będziesz pyłem lub szkieletem, tylko imieniem, a nawet już i imienia nie będzie” (V, 56).

${ }^{69}$ Marek Adamiec w książce „...Pomnik trochę niezupetny...”. Rzecz o apokryfach i poezji Zbigniewa Herberta (Gdańsk 1996) przekonuje, że Herbert był apologetą nicości, a jego poezja to głos rozpaczy. $Z$ jednej strony z tak radykalną tezą trudno się zgodzić, chociażby z racji złożoności i antynomialności poezji Herberta. $Z$ drugiej jednak takiego spojrzenia nie należy dyskredytować; z tego powodu recenzja Agnieszki Bielak Interpretacje i dowolności („Ethos” 2000, nr 4, s. 223-226) jest zbyt surowa. Z kolei Przemysław Czapliński w artykule Śmierć, czyli o niedoskonatości przekonuje, że śmierć w ujęciu Herberta jest drogą do nicości, równie absurdalną, jak życie; powodem ma być to, że w świecie poety żyje się i umiera bez racji. Zob. W. Pyczek, Próby poznawania Herberta, „Ethos” 2000, nr 4, s. 214. 
dostrzega równoważność wszystkich sądów, wobec czego nie potrafi wybrać między tak i nie. Pomimo jasnych przestróg Jezusa ${ }^{70}$ Pan Cogito gotów jest niekiedy przyjąć, że prawdy nie stanowi ani tak, ani nie, innym zaś razem, że może nią być jednocześnie tak i nie ${ }^{71}$. Bohater Herberta zatem, w przeciwieństwie do swego filozoficznego pierwowzoru, jest ciagle w drodze, podobnie zresztą, jak autor, który go wymyślił; poeta nie był wszak autorytatywnym i pouczającym kapłanem, lecz poszukującym artystą ${ }^{72}$, zmagającym się ze złożonością świata i wszystkich ludzkich spraw.

Ilustracją tej postawy jest głos sumienia, który niczego nie doradza ani nie odradza (Gtos wewnętrzny), okazuje się zatem bardziej enigmatyczny niż dajmonion Sokratesa, który wprawdzie nie podpowiadał, co czynić, jednak wyraźnie ostrzegał przed złem. Głos starożytnego mędrca był też bezwzględnym imperatywem, któremu nie sposób się sprzeciwić. Tymczasem głos wewnętrzny Pana Cogito jest wątły i niepewny, dlatego łatwo go zignorować, a nawet zagłuszyć, zwłaszcza że - zamiast rozwiązań - mnoży dylematy. Na takiej niepewności jednak polega prawdziwa wielkość i piękno ludzkiego życia (Nike która się waha $)^{73}$. Zgodnie wszak z przesłaniem dramatu Jaskinia filozofów ostateczna prawda jest zakryta; tak samo bowiem, jak żaden z uczniów Sokratesa nie potrafi odkryć tajemnicy osobowości mistrza (wszelkie zaś próby jej opisu wzajemnie się znosza), tak żaden mędrzec nie potrafi rozszyfrować zagadki świata (Pan Cogito a pop $)^{74}$. Ostatnim słowem ludzkiej mądrości okazuje się niepewność i wątpienie; chociaż jednak są one stanem trudnym, to jednak również pięknym, wyrażają wszak najpełniej naszą naturę ${ }^{75}$.

O sympatii Herberta do sceptycyzmu świadczy także wiersz Tomasz, opisujący historię Apostoła, który nie uwierzył w zmartwychwstanie Jezusa. Wprawdzie skarcony przez Mistrza porzucił wahanie, to jednak scena ta zdaje się świadczyć, że prawda może do nas przyjść wyłącznie w postaci bezpośredniego objawienia bożego. Tylko Bóg potrafi usunąć wszelkie dwuznaczności,

${ }^{70}$ Zob. „Niech wasza mowa będzie: Tak - tak, nie - nie, a co ponadto - pochodzi od złego" (Mt 5, 37).

${ }^{71}$ Zob. S. Barańczak, dz. cyt., s. 30, 77.

72 Zob. W. Kruszewski, Autorytet poetycki Zbigniewa Herberta, „Ethos” 2000, nr 4, s. 210-211.

73 Wiersz ten ma więcej znaczeń, które pomijam, z pewnością jednak obrazuje także słuszność postawy sceptyka. Nike była wszak mściwą i szowinistyczną boginią zwycięstwa; jeśli zatem się waha, to staje się boginią refleksji, a może nawet współczucia dla pokonanych. Zob. A. Zagajewski, dz. cyt., s. 170.

${ }^{74}$ Zob. M.K. Siwiec, Zbigniew Herbert - ku tajemnicy Sokratesa, „Filo-Sofija” 2010, nr 2, s. 18. Równie sceptyczny był Herbert wobec badań archeologicznych; z jednej strony przekonywał, że - jak w każdej nauce - możemy tu mieć do czynienia jedynie z hipotezami (którym można przeciwstawić silne kontrargumenty), z drugiej podkreślał, że za dużo wiemy o kłamstwach sztuki, lukrującej świat, aby ufać nawet źródłom. Zob. Z. Herbert, Labirynt nad morzem, dz. cyt., s. 40, 72.

75 Zob. J. Hartwig, Herbert, który się waha [w:] Poeci czytaja Herberta, dz. cyt., s. 120-121. Według Herberta tylko kołatka brzmi jednoznacznie. Zob. tamże. 
wskazując, na przykład, że zjawiający się uczniom Jezus nie jest upiorem wyobraźni, lecz zmartwychwstałym nauczycielem. Jeśli jednak człowiek miałby takie objawienie przyjąć, to nie powinien być wątpiącym Panem Cogito, lecz raczej walczącym z pokusą zwątpienia Panem Credo ${ }^{76}$. Tymczasem porzucenie wątpliwości i opowiedzenie się albo za tak, albo za nie, może być źródłem prześladowań, o czym świadczą więzienia i stosy. Niewykluczone, że właśnie z tego powodu Herbert ma nadzieję, iż Bóg nie potępia sceptyków ani niedowiarków, rozumiejąc ludzkie ograniczenia poznawcze: „a więc dozwolone jest wątpienie/ zgoda na pytanie/ coś warte jest czoło/ w zmarszczkach Leonarda" (Tomasz, s. 678). Podobny sens ma wiersz Homilia, w którym poeta przekonuje, że wątpiący (a nawet niepokorni) sceptycy także należą do ludu Bożego; niewykluczone zresztą, że to właśnie oni autentycznie szukają Boga, w przeciwieństwie do niewierzących (którzy Go neguja) i wierzących (którzy Go znaleźli).

Wahanie w zakresie spraw ostatecznych (takich jak istnienie Boga czy życie wieczne) nie znaczy, że Herbert to sceptyk totalny, negujący wszelkie oczywistości. Przeciwnie, jego poezja jest z jednej strony świadectwem, że sceptycyzm był przez niego łączony z postawą ironii, z drugiej, że nieprzekraczalną granicą wątpienia są podstawowe i jednoznaczne wartości moralne, których podważać nie wolno. Tam przecież, gdzie wchodzi w grę krzywda niewinnych, nie można się wahać ani zasłaniać niewiedzą; z tego powodu Pan Cogito jest miłośnikiem tautologii (Pan Cogito i wyobraźnia) ${ }^{77}$. Sceptycyzm nie ma bowiem nic wspólnego z moralnym relatywizmem; nie jest też zgodą na rozstrzyganie spornych kwestii przemocą. Przeciwnie, sceptycyzm to głos ostrożności, skoro bowiem możemy się mylić, to nie powinniśmy swojego punktu widzenia narzucać innym. Zarazem jednak sceptycyzm chroni przed działaniami ornamentatorów, którzy rzeczywistość chcą zastąpić fikcją. Wniosek ten sugeruje, że Pan Cogito - zawieszony między wiarą a zwątpieniem - jest postacią tragiczną, skazaną na wieczne (może nawet nieludzkie) wahanie między wyborem drogi w górę i drogi w dó $1^{78}$.

${ }^{76}$ Figurę tę wprowadza w swojej poezji ksiądz Alfred Marek Wierzbicki (tenże, Fotografia rodzinna, Lublin 2010; tenże, 76 wierszy, 2017). O ile jednak Pan Credo otwiera się na głos Boży, o tyle Herbertowski Pan Cogito jest raczej bogiem Janusem o dwu twarzach, zwróconych ku dwu przeciwnym stronom świata. Zob. S. Barańczak, dz. cyt., s. 31.

77 Szczególnie niebezpieczna jest zmiana znaczeń słów (jak nazwanie fałszu czy kłamstwa prawda). Zob. E. Hirsch, dz. cyt., s. 105. Nie wchodząc w szczegóły złożoności pojęcia tautologii w poezji Herberta, które daleko wykracza poza jego źródłowy (i trywialny) sens techniczny, znany z logiki formalnej, należy zauważyć, że kultura pozbawiona fundamentalnych i powszechnie akceptowanych oczywistości (właśnie „tautologii”), najprawdopodobniej nie mogłaby przetrwać. Ta konstatacja sugeruje również, że wielkie kryzysy kultury polegają na porzuceniu tautologii, zwłaszcza zaś na zmianie ich treści, kiedy to demokracja zaczyna być definiowana jako dyktatura proletariatu, wolność - jako zamęt czy anarchia a prawa człowieka - jako spisek elit czy grup interesów.

${ }^{78}$ Zdaniem Sochonia Epilog burzy świadczy o tym, że Herbert pokonał zwątpienie i odkrył jedność ze Stwórcą Wszechrzeczy. Zob. J. Sochoń, dz. cyt., s. 113. Z kolei Mateusz Werner 


\section{Bibliografia}

Adamiec M., „...Pomnik trochę niezupetny... ”. Rzecz o apokryfach i poezji Zbigniewa Herberta, Gdańsk 1996.

Barańczak S., Uciekinier z Utopii. O poezji Zbigniewa Herberta, Londyn 1984.

Bielak A., Interpretacje i dowolności, „Ethos” 2000, nr 4.

Bonowicz W., Otwarcie wiersza [w:] Poeci czytaja Herberta, zebr., oprac. A. Franaszek, Kraków 2009.

Borges J.L., Nieśmiertelność, tłum. D. Walasek-Elbanowska, „Literatura na Świecie" 1988, nr 12.

Borges J.L., Nieśmiertelny, tłum. M. Potok-Nycz [w:] tegoż, Alef, tłum. Z. Chądzyńska, M. Potok-Nycz, Warszawa 2003.

Borges J.L., Pamiętliwy Funes [w:] tegoż, Fikcje, tłum. A. Sobol-Jurczykowski, S. Zembrzuski, Warszawa 2003.

Brandstaetter R., Bardzo krótkie i nieco dtuższe opowieści, Poznań 1984.

Cyranowicz M., Herbertowskie inedita, „Ethos” 2000, nr 4.

Czapliński P., Śmierć, czyli o niedoskonatości [w:] Poznawanie Herberta, wybór, wstęp A. Franaszek, Kraków 1998.

Dybciak K., Gry i katastrofy, Warszawa 1980.

Dzień M., Bogowie Herberta, „Teksty Drugie” 2000, nr 3.

Garbol T., Kilka czystych taktów, „Ethos” 2000, nr 4.

Gutorow J., Herbert, pies i gwiazda [w:] Poeci czytaja Herberta, zebr., oprac. A. Franaszek, Kraków 2009.

Hartwig J., Herbert, który się waha [w:] Poeci czytają Herberta, zebr., oprac. A. Franaszek, Kraków 2009.

Herbert Z., Labirynt nad morzem, Warszawa 2000.

Herbert Z., Wiersze zebrane, oprac. R. Krynicki, Kraków 2008.

Hirsch E., Chlust zimnej wody, tłum. M. Heydel [w:] Poeci czytają Herberta, zebr., oprac. A. Franaszek, Kraków 2009.

Höffe O., Immanuel Kant, tłum. A.M. Kaniowski, Warszawa 2003.

Kijas Z., Niebo w domu Ojca, czyściec dla kogo, piekto w oddaleniu, Kraków 2010.

Kopciński J., Nastuchiwanie. Sztuki na gtosy Zbigniewa Herberta, Warszawa 2008.

Kornhauser J., „Struna światta” - między ocaleniem a niepokojem, „Teksty Drugie" 2000, nr 3.

Kruszewski W., Autorytet poetycki Zbigniewa Herberta, „Ethos” 2000, nr 4.

Maj B., Mój prywatny epizod [w:] Poeci czytaja Herberta, zebr., oprac. A. Franaszek, Kraków 2009.

Marek Aureliusz, Rozmyślania, tłum. M. Reiter, Warszawa 1984.

uważał, że Herbert był poetą sfrustrowanym, który kreował siebie na nieomylny autorytet i sędziego. Zob. W. Pyczek, dz. cyt., s. 213. Obie oceny są zbyt jednostronne; jeśli bowiem spojrzeć na Herberta przez pryzmat figury Pana Cogito, to był on raczej tragicznym (post)kartezjaninem. Zob. E. Hirsch, dz. cyt., s. 105. 
Martini C.M., Jakie piękno zbawi świat?, tłum. Z. Zwolska, „Ethos” 2000, nr 4. Montaigne M. de, Próby, t. 1-3, tłum. T. Żeleński-Boy, Warszawa 1985.

Najder Z., Ojczyzna i naród w poezji Zbigniewa Herberta, „Ethos” 2000, nr 4.

Nycz R., „Niepewna jasnośc” tekstu i „wierność interpretacji”. Wokót wiersza Zbigniewa Herberta „Pan Cogito opowiada o kuszeniu Spinozy”, „Teksty Drugie” 2000, nr 3.

Puzynina J., Niebo Herberta, „Ethos” 2000, nr 4.

Pyczek W., Próby poznawania Herberta, „Ethos” 2000, nr 4.

Sady W., Dzieje religii, filozofii i nauki. Od Pico della Mirandoli do Miguela Serveta, Kęty 2013.

Shallcross B., Zbigniewa Herberta podróż do zachwytu, „Teksty Drugie” 2000, nr 3.

Siemaszko P., Piękno jako odpowiedź. O malarskich fascynacjach Zbigniewa Herberta, „Ethos” 2000, nr 4.

Siwiec M.K., Zbigniew Herbert - ku tajemnicy Sokratesa, „Filo-Sofija” 2010, nr 2.

Siwiec M.K., Zbigniew Herbert - twórca i źródto. Droga do źródta i źródto w wierszu „Ścieżka”, „Filo-Sofija” 2013, nr 3.

Sochoń J., Bóg poety, „Ethos” 2000, nr 4.

Sosnowski A., „Epizod” [w:] Poeci czytaja Herberta, zebr., oprac. A. Franaszek, Kraków 2009.

Szram M., Ciato zmartwychwstate w myśli patrystycznej przetomu II i III wieku, Lublin 2010.

Tischner J., Myślenie w żywiole piękna, wybór, oprac. W. Bonowicz, Kraków 2005.

Tischner Ł., Gombrowicza milczenie o Bogu, Kraków 2013.

Tischner Ł., Sekrety manichejskich trucizn. Mitosz wobec zta, Kraków 2001.

Wierzbicki A.M., 76 wierszy, Lublin 2017.

Wierzbicki A.M., Fotografia rodzinna, Lublin 2010.

Williams B., Sprawa Makropulos: refleksje nad nuda niesmiertelności, tłum. T. Duliński [w:] tegoż, Ile wolności powinna mieć wola? i inne eseje z filozofii moralnej, tłum. T. Baszniak, T. Duliński, M. Szczubiałka, Warszawa 1999.

Zagajewski A., Niejasne przestanie [w:] Poeci czytaja Herberta, zebr., oprac. A. Franaszek, Kraków 2009. 